\title{
Perlindungan Hukum Terhadap Penyalahgunaan Akun Dalam Transaksi Elektronik Melalui Traveloka
}

\author{
Ferdy Arliyanda Putra ${ }^{1}$ \\ Universitas Trunjoyo Madura \\ ferliyandap@gmail.com \\ Lucky Dafira Nugroho \\ Universitas Trunojoyo Madura \\ lucky.dafira@trunojoyo.ac.id
}

\begin{abstract}
ABSTRAK
Model perdagangan saat ini mulai bergeser pada perdagangan melalui sistem elektronik yang biasanya disebut marketplace. Sebelum melakukan transaksi elektronik melalui sistem elektronik biasanya diminta oleh sistem untuk membuat akun atau yang biasa disebut sebagai identitas konsumen. Akun tersebut berisikan identitas, user, dan password untuk dapat melakukan transaksi. Dalam perkembangannya, marketplace tersebut menyediakan sistem paylater yang memudahkan pemilik akun/konsumen untuk membayar tagihan dikemudian hari atau dengan kata lain utang kepada marketplace tersebut. Ada suatu kasus dimana salah satu markeplace, traveloka, disalahgunakan oleh pihak ketiga yang tidak bertanggung jawab yaitu untuk membeli tiket dan menjual tiket dengan menggunakan akun milik orang lain. Dari permasalahn tersebut hendak mencari penyelesaian hukum dengan upaya melindungi konsumen/pemilik akun dan pemulihan kerugian pemilik akun/konsumen tersebut. Untuk menjawab permasalahan tersebut menggunakan metode penelitian hukum. Adapun hasil penelitian yang telah dilakukan adalah perlindungan hukum bagi pemilik akun adalah perlindungan hukum internal dan eksternal. Perlindungan hukum internal termaktub dalam syarat dan ketentuan yang tercantum dalam aplikasi traveloka yang dapat dijadikan dasar untuk meminta ganti rugi apabila ada penyalhgunaan akun. Selain itu, perlindungan hukum eksternal diatur dalam Pasal 31 PP 71/2019 tentang Penyelenggaraan Sistem dan Transaksi Elektronik dan Pasal 37 POJK Nomor 77/POJK.01/2016 Tentang Layanan Pinjam Meminjam Uang Berbasis Teknologi Informasi. Upaya pemulihan krugian dapa dilakukan melalui gugatan PMH ke pengadilan negeri.
\end{abstract}

Kata Kunci : perlindungan hukum, penyalahgunaan, akun, transaksi, elektronik

\section{ABSTRACT}

The current trading model began to shift on trading through electronic systems commonly called marketplaces. Before conducting electronic transactions through electronic systems are usually requested by the system to create an account or commonly referred to as the identity of the consumer. The account contains identity, user, and password to be able to make transactions. In its development, the marketplace provides a paylater system that makes it easier for account owners /consumers to pay bills in the future or in other words owe to the marketplace. There was a case where one of the markeplace, traveloka, was abused by an irresponsible third party that was to buy tickets and sell tickets using someone else's account. From the problem want to seek a legal settlement with efforts to protect the consumer / account owner and recovery of losses of the account owner / consumer. To answer the problem using legal research methods. The result of the research that has been done is legal protection for account owners is internal and external legal protection. Internal legal protection is contained in the terms and conditions listed in the traveloka application that can be used as a basis for seeking compensation if there is misuse of the account. In addition, external legal protection is stipulated in Article 31 PP 71/2019 on The Implementation of Electronic Systems and Transactions and Article 37 POJK Number 77/POJK.01/2016 concerning Information Technology-Based Money Lending Services. Efforts to recover krugian dapa done through a lawsuit PMH to the district court.

Keywords : legal protection, abuse, accounts, transactions, electronics. 


\section{PENDAHULUAN}

Kemajuan teknologi pada era milenial atau di era revolusi industry 4.0 ini sangat cepat perkembangannya dan tidak terhindarkan lagi dapat mempengaruhi gaya hidup di masyarakat yang kini menggunakan cara - cara yang lebih praktis dan efisien dengan bantuan yang salah satu contohnya adalah internet (interconnection network). Berdasarkan Kamus Besar Bahasa Indonesia (KBBI) internet merupakan "jaringan komunikasi elektronik yang menghubungan terhadap jaringan - jaringan komputer dan fasilitas komputer yang tersebar di seluruh dunia melalui telepon dan satelit". ${ }^{1}$ Internet saat ini sebagai media teknologi informasi modern yang berkembang dan menyebar di masyarakat di Indonesia maupun di seluruh dunia dimana dapat mempermudahkan proses perdagangan dan banyak juga digunakan dalam beragam aktivitas yang bermanfaat antara lain untuk mencari data dan berita, saling mengirim pesan melalui email, komunikasi melalui situs - situs jejaring sosial secara cepat, tepat dan efisien. ${ }^{2}$

Keberadaan teknologi internet pada era revolusi industri 4.0 membuka sebuah peluang dalam model pemasaran baru bagi produk produk ataupun sebuah jasa. Model pemasaran yang melalui internet saat ini dikenal dengan

\footnotetext{
1 Kamus Besar Bahasa Indonesia (KBBI), "Internet", dikutip dari http://www.google.com/amp/s/kbbi.web.id/interent.ht $\underline{\mathrm{ml}}$, <diunduh tanggal 13 maret 2020>

2 Geistiar Yoga Pratama, "Perlindungan Hukum Terhadap Data Pribadi Pengguna Jasa Transportasi Online Dari Tindakan Penyalahgunaan Pihak Penyedia Jasa Berdasarkan Undang - Undang Nomor 8 Tahun 1999 Tentang Perlindungan Konsumen", Diponegoro Law Journal, Volume 5 Nomor 3, 2016, Diponegoro, hlm. 1-2.
}

electronic commerce atau disingkat e-commerce yaitu sebuah proses suatu perdagangan seperti menjual, membeli dan tukar menukar produk ataupun jasa yang menggunakan secara digital dengan menggunakan internet dalam transaksi bisnis atau jual beli barang ataupun jasa antara individual dengan individual atau penjual dengan pembeli. Menurut Prihartono dan Jonathan sarwono "model transaksi e-commerce merupakan transaksi yang berbeda dengan transaksi konvensial karena transaksi ini hanya menggunakan internet untuk berkomunikasi tanpa tatap muka". 3 Transaksi e-commerce dalam dunia bisnis memiliki sebuah keunggulan secara efisien dan efektif sehingga menjadi daya tarik sendiri bagi perusahaan yang melakukan transaksi secara e-commerce bisa memperoleh secara efisien dari segi pemasaran, overhead cost, tenaga kerja dan juga perusahaan bisa membuat sebuah virtual shop 24 jam non stop dengan menampilkan berbagai informasi tentang produk ataupun jasa serta prosedur pembelian secara online. 4

Pemenuhan kebutuhan - kebutuhan oleh masyarakat sangatlah banyak di era yang sudah canggih ini, hal tersebut ditegaskan oleh Eri Wuria Dewi, dimana "terdapat peningkatan pembelian produk - produk dan meningkatnya pelaku usaha yang menawarkan sebuah jasa yang

3 Prihartono dan Jonathan Sarwono, Perdagangan Online : Cara Bisnis di Internet, Jakarta, PT Elex Media Komputindo, 2012, hlm. 1.

4 Didi Achjari, "Potensi Manfaat dan Problem Di E-commerce", Jurnal Ekonomi dan Bisnis Indonesia, Volume 15 Nomor 3, 2000, Yogyakarta, hlm. 389. 
sangat tinggi kepada masyarakat, 5 namun tidak jarang dalam kegiatan melalui transaksi media internet ini dapat menimbulkan sebuah masalah adanya ketidakpastian dan perkembangan internet yang terus berubah rubah sehingga dapat menimbulkan kerugian terhadap keamanan rahasia informasi personel. 6

Pemilik akun sebagai konsumen juga harus lebih teliti atau hati - hati dalam hal menggunakan jasa ataupun pembelian produk dengan menggunakan e-commerce khususnya yang banyak terjadi sekarang yaitu penyalahgunaan akun dalam transaksi jual beli melalui marketplace dan pengambilan data pribadi secara online serta disebarluaskan. Adanya Undang - Undang Nomor 8 Tahun 1999 Tentang Perlindungan Konsumen, selanjutnya disebut UUPK konsumen dilindungi hak haknya oleh Undang - Undang dijamin haknya apabila mengalami kerugian dan pelaku usaha wajib untuk bertanggung gugat menurut Rosmawati.

Konsumen adalah setiap orang yang melakukan pemakaian terakhir sebuah produk barang ataupun jasa yang diperoleh dari pelaku usaha dan untuk digunakan diri sendiri, keluarga atau orang lain dan tidak perdagangkan kembali. ${ }^{7}$ Pasal 1 ayat (1) UUPK disebutkan yang dimaksud perlindungan konsumen adalah

5 Eli Wuria Dewi, Hukum Perlindungan Konsumen, Yogyakarta, Graha Ilmu, 2015, hlm. 1.

6 Rika Mawarni, "Perlindungan Hukum Bagi Para Pihak Dalam Transaksi E-commerce Melalui Facebook", Jurnal Hukum Progresif, Volume X Nomor 1, 2016, Bangka Belitung, hlm. 1643.

7 Rosmawati, Pokok - pokok Hukum Perlindungan Konsumen, Depok, Prenadamedia Group, 2018, hlm. 2-5.
"Segala upaya yang dapat menjamin adanya kepastian hukum atau payung hukum untuk memberi perlindungan kepada konsumen terhadap pelaku usaha". Akhir - akhir ini masalah tentang perlindungan konsumen menjadi hal yang sangat berkepanjangan, yang dalam menyelesaikan sebuah kasus sering sekali menemukan jalan buntu atau yang dapat merugikan konsumen.

Penjual memperlakukan pembeli sebagai bahan untuk mendapatkan sebuah keuntungan yang semaksimal mungkin dengan pengeluaran yang sangat sedikit dan bukan sebagai mitra usaha dalam transaksi jual beli barang atau jasa. Para penjual memakai prinsip ekonomi untuk mendorong melakukan tindakan yang dapat membuat kerugian bagi pembeli. Hal ini disebabkan karena lemahnya posisi dalam konsumen dibandingkan oleh pelaku usaha. Menurut Shidarta "umumnya pelaku usaha hanya berlindung dalam perjanjian baku yang dibuat oleh kedua belah pihak antara konsumen dan pelaku usaha dan tidak adanya alternatif yang dilakukan oleh konsumen yang sudah menjadi rahasia umum dalam dunia industri di Indonesia".8

Penjual dengan adanya model transaksi $e$ commerce banyak menawarkan sebuah jasa melalui media elektronik dengan menggunakan internet seperti aplikasi Traveloka yang menawarkan sebuah jasa pembelian tiket pesawat, tiket kereta api, tiket bus dan hotel, sehingga Seiring berkembangnya teknologi yang

8 Shidarta, Hukum Perlindungan Konsumen Indonesia, Jakarta, Gramedia Widiasarana Indonesia, 2006, hlm. 2. 
semakin canggih dalam melakukan transaksi tidak harus dengan tatap muka dan hanya menggunakan internet untuk membelinya.

Pemilik akun adalah data tentang identitas virtual atau data pribadi seseorang di dunia maya yang sudah di daftarkan dalam sebuah aplikasi untuk login. 9 Pemilik akun bisa disebut konsumen bila pemilik akun sudah membeli dan memakai sebuah barang atau jasa yang sudah ada. Pasal 1 ayat (2) selanjutnya disebut UUPK yang dimaksud konsumen adalah "Setiap orang pemakai barang dan/atau jasa yang tersedia dalam masyarakat, baik bagi kepentingan diri sendiri, keluarga, orang lain, maupun makhluk hidup lain dan tidak untuk diperdagangkan". Pemilik akun dapat menjadi konsumen apabila pemilik akun membeli sebuah barang ataupun jasa dan sudah menggunakannya. Hubungan hukum pemilik akun dalam transaksi Traveloka yaitu adanya transaksi jual beli jasa antara konsumen pemilik akun dengan vendor pemilik jasa dengan melalui sebuah aplikasi marketplace yaitu Traveloka sebagai tempat atau perantara sebuah jasa dengan cara pembayaran secara online.

Kemajuan dalam sistem pembayaran dalam hal transaksi membentuk pembayaran dengan cara non tunai atau yang disebut pembayaran secara elektronik yang sering disebut juga pembayaran secara online. Traveloka dengan perkembangan teknologi pada saat ini, secara resmi menggunakan layanan pembayaran

9 Temukan Pengertian, "Pengertian Account Dalam Internet dan Jenis - jenis Account', dikutip dari http://www.temukanpengertian.com/2013/01/pengertia n-account.html, <diunduh tanggal 13 Maret 2020>. terbaru yaitu paylater, fitur yang dapat membayar di kemudian hari seperti kartu kredit yang melakukan transaksi dapat membayar dengan jangka waktu 30 hari setelah melakukan transaksi atau dapat membayar secara mencicil dengan durasi 1- 2 bulan dengan bunga yang kecil. Fitur paylater sangat membantu pemilik akun sebagai konsumen bila ingin membeli tiket pesawat, tiket kereta api, hotel dan lain - lain di Traveloka, tetapi banyak kejadian dalam transaksi pembelian jasa yang menggunakan aplikasi Traveloka dan fitur paylater yang disalahgunakan oleh pihak ketiga yang tidak bertanggung jawab yaitu untuk membeli tiket dan menjual tiket.

Ada sebuah Kasus yang terjadi di masyarakat adanya penyalahgunaan akun yang pemilik akun Traveloka mendapatkan notifikasi e-mail bahwa nomor HP dan e-mail yang sudah didaftarkan di akun Traveloka telah di hapus, sehingga sebagai pemilik akun tidak dapat login. Menanggapi hal tersebut pemilik akun menghubungi call center Traveloka, setelah menunggu cukup lama tiba - tiba ada 10 (sepuluh) notifikasi rincian pembayaran Paylater Traveloka ke email pemilik akun semuanya untuk pembelian Jatim Park 2 (Batu Secret Zoo \& Museum Satwa) Tickets - Easy Access 19Feb-2019 dengan menggunakan limit Paylater pemilik akun sebesar Rp. 3.000.000,-. Hal tersebut sangat merugikan konsumen karena dalam aplikasi Traveloka sangat mudah disalahgunakan oleh orang yang tidak bertanggung jawab ${ }^{10}$, tetapi Traveloka sendiri

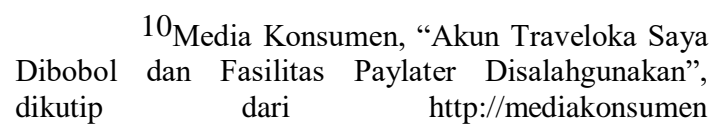


tidak memberikan sebuah tanggung jawab kepada konsumen yang telah dirugikan dan Traveloka tidak bertanggung jawab bila akun Traveloka paylater digunakan oleh pihak ketiga. Traveloka membuat klausula atau ketentuan yang menyatakan Traveloka tidak akan bertanggung jawab atas setiap kejadian yang terjadi seperti penipuan atau penyalahgunaan akun oleh pihak ketiga selain itu traveloka mengatakan tidak memiliki kewajiban untuk melakukan pengembalian pembayaran atau membayarkan kembali sebagai akibat dari penyalahgunaan akun yang digunakan oleh pihak ketiga. Akun yang disalahgunakan dan menggunakan fitur paylater untuk membeli tiket tagihan tetap di bebankan kepemilik akun asli dan klausula tersebut dapat merugikan pihak pemilik akun. Pada Pasal 3 huruf (c), selanjutnya disebut UUPK menjelaskan bahwa "meningkatkan pemberdayaan konsumen dalam memilih, menentukan dan menuntut hak haknya sebagai konsumen". Pelaku usaha seharusnya dapat memberikan hak atas kenyamanan, keamanan dan keselamatan dalam mengkonsumsi barang dan/atau jasa.

Gambar 1.1 Syarat \& Ketentuan Akun Pengguna Sumber : http://m.traveloka.com/id-id/

Gambar 1.1 menjelaskan bahwa syarat dan ketentuan yang dibuat oleh Traveloka tentang apa yang harus dilakukan oleh pemilik akun terhadap akun yang sudah terdaftar dengan mengisi data pribadi. Pemilik akun tidak boleh mengizinkan pihak lain untuk menggunakan

9. AKUN PENGGUNA

9.1 Untuk tujuan pendaftaran, kami akan mengumpulkan dan memproses informasi pribadi anda, seperti nama, alamat surat elektronik (surel), dan nomor telepon genggam anda ketika anda melakukan pendaftaran. Anda harus menyediakan kami dengan informasi yang akurat, lengkap dan terkini dan setuju untuk menyediakan kami dengan bukti identitas diri yang mungkin kami minta dengan alasan yang jelas.

92 Hanya anda yang berhak untuk menggunakan akun anda sendiri dan anda menyatakan dan menjamin bahwa anda tidak akan mengizinkan pihak lain untuk menggunakan identitas atau akun anda untuk alasan apapun, kecuali diizinkan oleh Traveloka.

9.3 Anda tidak dapat mengalihkan atau memindahkan akun anda kepada pihak lain manapun.

9.4 Anda harus menjaga keamanan dan kerahasiaan kata sandi akun anda dan identifikasi yang kami sediakan untuk anda. Dalam hal terdapat pengungkapan atas kata sandi anda, dalam hal apapun juga yang menyebabkan adanya pengguna yang tidak sah atas akun atau identitas anda, pesanan yang diterima atas pengqunaan yang tidak sah tersebut akan tetap dianggap sebagai pesanan yang sah dan kami akan memproses pesanan tersebut. Anda dengan ini menyatakan bahwa Traveloka tidak bertanggung jawab atas setiap kerugian atau kerusakan yang timbul atas penyalahgunaan akun anda tersebut.

9.5 Jika anda tidak lagi mempunyai kontrol atas akun anda, anda dibutuhkan untuk secepatnya memberitahukan kami (e.g. akun anda diretas dengan cara apapun atau telepon anda dicuri) sehingga kami dapat memblokir sementara dan/atau menonaktifkan akun anda sebagaimana diperlukan. Harap dicatat bahwa anda bertanggung jawab atas penggunaan akun anda dan mungkin bertangqung jawab atas akun anda meskipun dalam hal akun anda disalahgunakan oleh pihak lain.

9.6 Traveloka memiliki seluruh hak untuk memblokir sementara, menghapus, atau menonaktifkan akun Pengguna atas kebijakan kami sendiri dan untuk sebab apapun tanpa memberikan alasan atas pemblokiran, penghapusan atau penonaktifan akun Pengguna tersebut. Alasan dari pemblokiran, penghapusan, atau penonaktifan akun Pengguna dapat termasuk namun tidak terbatas kepada:

j. Pelanggaran Syarat ini.

k. Larangan di peraturan.

Penipuan atau pencurian (atau indikasi atau sangkaan penipuan atau penipuan

Kecurigaan adanya tindak kriminal.

1. Pesanan yang mencurigakan

Pengguna memberikan informasi yang tidak akurat salah atau menyesatkan.

p. Melakukan perbuatan yang tidak pantas, ancaman, atau hinaan

Menolak memberikan informasi.

Adanya hambatan praktis.

5. Kesulitan atau kendala komunikasi, atau

. Pengguna termasuk ke dalam "daftar hitam" atau "daftar pengamatan" oleh pemerintah atau organisasi international. 
akunnya atau mengalihkan ke pihak lain untuk melakukan transaksi bila tidak ada izin dari pihak Traveloka. Syarat dan ketentuan yang dibuat oleh Traveloka sebagai pemilik akun bertanggung jawab secara penuh dan menjelaskan bahwa pihak Traveloka tidak bertanggung jawab atas kerugian atau kerusakan yang terjadi kepada pemilik akun karena adanya penyalahgunaan akun yang disalahgunakan oleh pihak ketiga. Pada pasal 37 Peraturan Otoritas Jasa Keuangan Nomor 77 /POJK.01/2016 Tentang Layanan Pinjam Meminjam Uang Berbasis Teknologi Informasi bahwa "penyelenggara wajib bertanggung jawab atas kerugian pengguna yang timbul akibat kesalahan dan/atau kelalaian, Direksi, dan/atau pegawai penyelenggara”.

Berdasarkan fakta - fakta diatas, maka menjadi suatu permasalahan apabila pihak traveloka tetap tidak memberikan kenyamanan atau perlindungan terhadap pemilik akun dengan demikian perlu adanya perlindungan hukum terhadap adanya penyalahgunaan pemilik akun pengguna dalam transaksi pelayanan jasa melalui Traveloka. Berdasarkan uraian latar belakang diatas, maka dapat di rumuskan masalah sebagai berikut :

1. Bagaimana bentuk perlindungan hukum terhadap pemilik akun Traveloka yang akunnya disalahgunakan oleh pihak ketiga $?$

2. Bagaimana upaya hukum untuk memulihkan kerugian pemilik akun Traveloka yang disalahgunakan oleh pihak ketiga ?

\section{METODE PENELITIAN}

Metode penelitian yang digunakan dalam penelitian ini adalah penelitian hukum dengan jenis penelitian yuridis normatif. Dimana berusaha mengkaji isu hukum dengan memfokuskan pada penerapan hukum positif dan kaidah - kaidah hukum. Pendekatan yang digunakan adalan pendekatan perundang undangan (statue approach) dan pendekatan konseptual (conceptual approach). Pendekatan perundang - undangan akan digunakan untuk mengkaji semua regulasi yang terkait dengan permasalahan dan menjadi dasar analisa untuk memberikan penyelesaian hukum.

\section{HASIL DAN PEMBAHASAN}

1. Perlindungan Hukum Terhadap Penyalahgunaan Akun Dalam Transaksi Elektronik

Perlindungan hukum menurut Serlika Aprita adalah "Perlindungan yang dibuat untuk subyek hukum yang bersifat preventif maupun yang bersifat represif, baik yang tertulis maupun yang tidak tertulis" dan memiliki sebuah gambaran bahwa perlindungan hukum merupakan suatu keadilan, ketertiban, kepastian, kedamaian dan kemanfaatan dimana hukum yang mempunyai persepsi tersebut. 11

Perlindungan hukum Menurut $\mathrm{M}$. Isnaeni pada dasarnya perlindungan hukum dibagi menjadi 2 yaitu perlindungan hukum

11 Serlika Aprita, Perlindungan Hukum Bagi Pemegang Saham Minorita, Kreditor Karyawan Atas Akuisisi Perusahaan, Jember, CV. Pustaka Abadi, 2019, hlm. 37. 
secara internal dan perlindungan hukum secara eksternal. Perlindungan hukum internal yaitu hukum yang pada dasarnya dibuat oleh kedua belah pihak sendiri pada saat menyusun sebuah perjanjian dimana waktu membuat klausula - klausula kontrak, kedua belah pihak menginginkan kepentingannya berdasarkan atas dasar kata sepakat. Demikian juga pada segala resiko yang sudah terjadi dapat dilihat pada klausula - klausula yang telah dibuat atas dasar kata sepakat, sehingga dengan adanya klausula - klausula yang telah disusun bersama dapat memperoleh perlindungan hukum yang berimbang atas persetujuan kedua belah pihak. Perihal pelindungan hukum internal itu baru dapat diwujudkan oleh kedua belah pihak apabila kedudukan hukum para pihak relatife berimbang, sehingga dengan asas kebebasan berkontrak masing - masing para pihak yang melakukan perjanjian itu memiliki keleluasaan untuk menyatakan kehendak sesuai kepentingan masing - masing. Perlindungan hukum eksternal yaitu yang disusun oleh penguasa lewat regulasi bagi kepentingan pihak yang lemah, "sesuai hakekat aturan perundang yang tidak boleh memberatkan salah satu pihak dan bersifat memihak kesalah satu pihak". 12 Secara proporsional juga wajib diberikan perlindungan hukum yang seimbang sedini mungkin kepada pihak yang lainnya, pada

\footnotetext{
12 Moch. Isnaeni, Pengantar

Hukum Jaminan Kebendaan, Surabaya, PT.

Revka Petra Media, 2016, hlm. 159-163
}

awal dibuatnya perjanjian salah satu pihak lebih relatife lebih kuat atau lebih dominan dari pada pihak mitranya. 13 Perlindungan hukum bagi pemilik akun dalam perlindungan hukum secara internal yaitu dalam perkembangan teknologi fintech yang sangat cepat dalam teknologi informasi dan komunikasi telah memunculkan sebagai inovasi baru yang disebut Fintech yang merupakan sebuah transaksi jual beli dengan menggunakan computer atau smartphone sehingga dapat memudahkan, cepat dan praktis dalam melakukan transaksi tanpa melakukannya dengan tatap muka seperti Traveloka yang sangat diminati oleh masyarakat dalam melakukan pembelian tiket kereta, pesawat dll. Jual beli di aplikasi Traveloka sebelum melakukan perjanjian atau kontrak pemilik akun harus mempelajari dan memperhatikan apa yang di berikan oleh pihak Traveloka melalui syarat dan ketentuan. Perjanjian baku yang berhubungan dalam isi yang sudah diatur secara sepihak oleh pihak Traveloka yang berisi hak - hak dari Traveloka dan kewajiban dari pemilik akun yang seharusnya dalam membuat perjanjian lebih mementingkan hak - hak dari pemilik akun dan kewajiban - kewajiban dari Traveloka. Apalagi Traveloka mengalihkan kewajibannya yang seharusnya menjadi

13 Sigit Priyambodo, Perlindungan Hukum Bagi Nasabah Debitur Terhadap Penetapan Bunga Bank Yang Tidak Sesuai Dengan Peraturan Perundang - Undangan Dalam Perjanjian Kredit, Jurnal Media Hukum dan Peradilan, Vol. 05 Nomor 1, 2019, Surabaya, hlm. 150 
tanggung jawabnya kepada pemilik akun sehingga hal tersebut dapat merugikan pemilik akun. ${ }^{14}$

Kesepakatan yang dibuat oleh kedua belah pihak akan mengikat dan menjadi hukum yang harus ditaati oleh mereka yang melakukan kesepakatan sehingga harus ada perlindungan hukum. Hukum yaitu peraturan peraturan atau sanksi serta norma yang dibuat untuk mengatur tingkah laku manusia dalam melindungi keadilan, ketertiban membuat kedisiplinan dan untuk mencegah supaya tidak terjadi kegaduhan di masyarakat. Hubungan hukum merupakan interaksi antara individu dengan individu lainnya yang dapat menimbulkan sebuah hak dan kewajiban sehingga dapat saling mengikat diri yang mempunyai akibat hukum yang sudah ada pada para pihak serta mengikat diri dalam melakukan perjanjian. Hubungan hukum dapat timbul apabila

1. Karena adanya kesepakatan dan perjanjian yang dibuat antara kedua belah pihak.

2. Karena Undang-Undang mewajibkannya.

Hubungan hukum antara pemilik akun Traveloka dengan Vendor pemilik jasa yang terdapat pada aplikasi Traveloka yaitu adanya interaksi antara kedua pihak dalam melakukan transaksi jual beli yang sudah menimbulkan sebuah

14 Sukarmi, Cyber Law Kontrak Elektronik Dalam Bayang - Bayang Pelaku Usaha, Bandung, Pustaka Sutra, hlm. 101. hak dan kewajiban sehingga dapat saling mengikat para pihak dalam melakukan kesepakatan atau perjanjian. Pembuatan perjanjian yang diatur dalam terms and conditions Traveloka yang dilakukan oleh pihak Traveloka dengan pemilik akun yaitu sebagai contoh kesepakatan yang dilakukan oleh kedua belah pihak antaranya pada poin ke 9 akun pengguna yang menyatakan "jika anda tidak memiliki control atas akun yang anda miliki seperti diretasnya akun atau disalahgunakan akun, anda harus memberitahukan kami secepatnya sehingga akun anda akan diblokir sementara atau menonaktifkan akun anda" perjanjian yang diberikan oleh Traveloka ini kepada pemilik akun menjelaskan bahwa pihak Traveloka akan memblokir sementara akun yang telah digunakan oleh pihak - pihak yang tidak bertanggung jawab. Suatu kesepakatan yang dibuat oleh kedua belah pihak yang dapat menimbulkan sebuah akibat hukum. Akibat hukum dalam sebuah kesepakatan atau perjanjian berdasarkan Pasal 1338 KUHPerdata yang dapat meliputi tiga macam yaitu :

1. Perjanjian bersifat mengikat para pihak hal ini sama dengan bunyi pasal 1338 ayat 1 KUHPerdata yang menyatakan bahwa semua perjanjian yang dibuat secara sah berlaku sebagai undang undang bagi para pihak yang membuatnya. 
2. Suatu perjanjian tidak dapat ditarik Kembali kecuali berdasarkan ada kata sepakat oleh kedua belah pihak juga bisa berdasarkan alasan - alasan yang dibenarkan oleh undang - undang pasal 1338 ayat 2 KUHPerdata.

3. Suatu perjanjian harus dilaksanakan dengan iktikad baik pasal 1338 ayat 3 . Perjanjian antara kedua belah pihak yang salah satu pihak tidak didasari dengan iktikad baik, misalnya didasari untuk motif melakukan penipuan atau penggelapan sehingga berpotensi batal demi hukum karena melanggar salah satu asas perjanjian yaitu sebab yang halal. 15

Menurut subekti istilah perjanjian sebagai makna dari "overeenkoms" selanjutnya untuk makna dari "verbintenissen" digunakan dalam kata perikatan sedangkan berdasarkan schut arti dari perikatan "merupakan hubungan hak hak kebendaan kedua pihak dalam hal seseorang ( Kreditur ) dapat menuntut dari seseorang lagi ( Debitur ) pelaksanaan suatu prestasi atau kewajiban memberikan jaminan".16 Pembuatan perjanjian yang diatur oleh Traveloka dalam syarat dan ketentuan harus diperhatikan oleh para pihak yaitu syarat sahnya perjanjian atau kontrak yang terdapat pada pasal 1320

15 Yusmita, dkk, Perlindungan Hukum Terhadap Penerima Pinjaman Uang Berbasis Teknologi Informasi, Jurnal Akrab Juara, Vol. 4 Nomor 5, Surabaya, hlm 178.

16 Sigit Priyambodo, Op.cit.,
Kitab Undang - Undang Hukum Perdata yang mengatur 4 syarat :

1. Sepakat mereka yang mengikat dirinya;

2. Kecakapan untuk membuat suatu perikatan;

3. Suatu hal tertentu;

4. Suatu sebab yang halal;

Syarat yang telah di tetapkan pada syarat kesatu serta syarat kedua dalam Pasal 1320 KUHPerdata yaitu syarat subyektif yang bila tidak terpenuhi apa yang telah di tetapkan maka konsekuensinya perjanjian itu dibatalkan, sedangkan syarat ketiga serta syarat keempat pasal 1320 KUHPerdata syarat obyektif yang apabila tidak terpenuhi yang telah ditetapkan maka perjanjian itu batal demi hukum. Dalam syarat dan ketentuan yang diatur oleh pihak Traveloka meliputi : 17

1. Lingkup Layanan Kami

2. Pembatalan

3. Permintaan Khusus

4. Saran Perjalanan

5. Peringkat

6. Harga dan Promosi

7. Biaya Tambahan dan Pengembalian Dana

8. Biaya Tambahan Dari Hotel

9. Akun Pengguna

10. Program Kesertaan

11. Detail dan Prosedur Pembayaran

12. Pembayaran dengan Kartu Kredit \& Penipuan

17 Traveloka, dikutip dari https://www.traveloka.com/id-id/termsandconditions, diakses pada tanggal 20 juni 2020.

Universitas Trunojoyo Madura 
13. Hak dan Kewajiban

14. Hak untuk Konten Pengguna

15. Pembatasan Penggunaan

16. Hak Kekayaan Intelektual

17. Klaim Pelanggaran hak Kekayaan Intelektual

18. Disclaimer

19. Batasan Tanggung Jawab

20. Ganti Rugi

21. Tautan dan konten Pihak Ketiga

22. Penghentian

23. Privasi

24. Hukum yang Mengatur

25. Penyelesaian Perselisihan

26. Umum

27. Force Majeure

28. Tentang Traveloka - FAQ

Perikatan dengan membuat syarat dan ketentuan oleh pihak Traveloka menimbulkan hak dan kewajiban harus diletakkan secara seimbang dan tidak boleh timbang ( memberatkan salah satu pihak ).

Pada Pasal 36 Peraturan Otoritas Jasa Keuangan Nomor 77 /POJK.01/2016 Layanan Pinjam Meminjam Uang Berbasis Teknologi Informasi yang mengatakan bahwa :

a. Dalam hal penyelenggara menggunakan perjanjian baku, perjanjian baku tersebut wajib disusun sesuai dengan ketentuan peraturan perundang undangan.

b. Perjanjian baku sebagaimana dimakud pada ayat (1) yang digunakan oleh penyelenggara dilarang;. c. Menyatakan pengalihan tanggung jawab atau kewajiban penyelenggara kepada pengguna. dan

d. Menyatakan bahwa pengguna tunduk pada peraturan baru, tambahan, lanjutan dan/ atau perubahan yang dibuat secara sepihak oleh penyelenggara dalam periode pengguna mafaatkan layanan.

Pada Pasal 1 ayat 2 Undang - undang Nomor 11 Tahun 2008 Tentang Informasi dan Transaksi Elektronik menjelaskan bahwa "Transaksi elektronik adalah perbuatan hukum yang dilakukan dengan menggunakan computer, jaringan computer, dan/atau media elektronik lainnya". Transaksi elektronik seperti Traveloka yang merupakan penyedia jasa yang dapat memudahkan masyarakat dalam membeli atau memesan sebuah tiket kereta, pesawat, hotel dll dengan segala kemudahan untuk membantu masyarakat. Di dalam pasal 9 Undang - undang Nomor 19 Tahun 2016 tentang perubahan atas Undang - undang Nomor 11 Tahun 2008 Tentang Informasi dan Transaksi Elektronik bahwa "pelaku usaha yang menawarkan produk melalui sistem elektronik yang menyediakan informasi yang lengkap dan benar berkaitan dengan syarat kontrak, produsen, dan produk yang ditawarkan”.

Transaksi jual beli dengan menggunakan teknologi atau digital tidak boleh bertentangan dengan Undang undang Nomor 19 Tahun 2016 tentang perubahan atas Undang - undang Nomor 11 
Tahun 2008 Tentang Informasi dan Transaksi Elektronik. Pelaku usaha yang memberikan sebuah produk barang atau jasa dengan menggunakan system elektronik wajib memberikan informasi yang lengkap serta jelas yang berhubungan dengan syarat - syarat yang dibuat. Transaksi jual beli dengan cara melakukan transaksi elektronik juga diatur dalam Pasal 48 Peraturan Pemerintah Nomor 71 Tahun 2019 Tentang Penyelenggaraan sistem dan Transaksi Elektronik (PSTE) menyatakan :

1) Pelaku usaha yang menawarkan produk melalui system elektronik wajib menyediakan informasi yang lengkap dan benar berkaitan dengan syarat kontrak, produsen, dan produk yang ditawarkan.

2) Pelaku usaha wajib memberikan kejelasan informasi tentang penawaran kontrak atau iklan.

3) Pelaku usaha wajib memberikan batas waktu kepada konsumen untuk mengembalikan barang yang dikirim apabila tidak sesuai dengan perjanjian atau terdapat cacat tersembunyi.

4) Pelaku usaha wajib menyampaikan informasi mengenai barang yang telah dikirim.

5) Pelaku usaha tidak dapat membebani konsumen mengenai kewajiban membayar barang yang dikirim tanpa dasar kontrak.

Perlindungan hukum eksternal dalam hal melindungi pemilik akun telah menerbitkan Undang - undang untuk mencegah adanya ketidakseimbangan dalam transaksi jual beli melalui teknologi dalam syarat dan ketentuan yang dibuat oleh pihak Traveloka bila terjadi adanya penyalahgunaan akun yang dilakukan oleh pihak ketiga sehingga merugikan pemilik akun Traveloka. Akun sendiri memiliki pengertian yang memuat tentang data - data milik seseorang yang seperti data nama, password serta data diri atau identitas seseorang yang terdapat dalam dunia maya dan akun di dalamnya tersebut telah memuat data pribadi seseorang tertentu seperti NIK, tanggal lahir, tempat tinggal, nomor kartu kredit serta data itu harus dijaga, dirawat kebenaran yang telah teridentifikasi dalam sistem elektronik. Perlindungan data pribadi yang terdapat di akun harus dijaga kerahasiannya untuk menghindari adanya ancaman kejahatan yang ada di dunia maya seperti penyalahgunaan akun yang dilakukan pihak yang tidak bertanggung jawab. Pada Pasal 14 ayat (1) Peraturan Pemerintah Nomor 71 Tahun 2019 Tentang Penyelenggaraan Sistem dan Transaksi Elektronik menjelaskan bahwa : "Penyelenggara sistem elektronik wajib melaksanakan prinsip perlindungan data pribadi dalam melakukan pemrosesan data pribadi meliputi" :

1. Pengumpulan data pribadi dilakukan secara terbatas dan spesifik, sah secara hukum, adil dengan sepengetahuan dan persetujuan dari pemilik data pribadi. 
2. Pemroresan data pribadi dilakukan sesuai dengan tujuannya.

3. Pemroresan data pribadi dilakukan dengan menjamin hak pemilik data pribadi.

4. Pemroresan data pribadi dilakukan secara akurat, lengkap, tidak menyesatkan, mutakhir, dapat dipertanggungjawabkan, akses dan pengungkapan yang tidak sah, serta pengubahan atau perusakan data pribadi.

5. Pemroresan data pribadi dilakukan dengan melindungi keamanan data pribadi dari kehilangan, penyalahgunaan, akses dan pengungkapan yang tidak sah, serta pengubahan atau perusakan data pribadi.

6. Pemroresan data pribadi dilakukan dengan membe ritahukan tujuan pengumpulan, aktivitas pemroresan, dan kegagalan perlindungan data pribadi.

7. Pemroresan data pribadi dimusnahkan dan/atau dihapus kecuali masih dalam masa retensi sesuai dengan kebutuhan berdasarkan peraturan perundang undangan.

Selain itu terdapat pada Pasal 14 ayat (5) Peraturan Pemerintah Nomor 71 Tahun 2019 Penyelenggara Sistem dan Transaksi Elektronik menjelaskan bahwa: Jika terjadi kegagalan dalam perlindungan terhadap data pribadi yang dikelolanya, penyelenggara sistem elektronik wajib memberitahukan secara tertulis kepada pemilik data pribadi. Dalam hal ini syarat dan ketentuan yang dibuat oleh Traveloka apabila terjadi penyalahgunaan akun, pihak Traveloka tidak memberikan tanggung jawab tetapi tanggung jawabnya dibebankan kepada pihak pemilik akun sehingga tidak ada mekanisme seperti pada pasal 31 Peraturan Pemerintah Nomor 71 Tahun 2019 Tentang Penyelenggara Sistem dan Transaksi Elektronik bahwa : Penyelenggara sistem elektronik wajib melindungi penggunanya dan masyarakat luas dari kerugian yang ditimbulkan oleh sistem elektronik yang diselenggarakan.

Selain mekanisme yang diatur dalam pasal 31 Peraturan Pemerintah Nomor 71 Tahun 2019 Tentang Penyelenggara Sistem dan Transaksi Elektronik. Perlindungan pemilik akun Traveloka diatur juga dalam Pasal 26 Peraturan Otoritas Jasa Keuangan Nomor 77/POJK.01/2016 Tentang Layanan Pinjam Meminjam Uang Berbasis Teknologi Informasi yang menjelaskan penyelenggara wajib menjaga kerahasiaan, keutuhan, dan ketersediaan data pribadi, data transaksi, dan data keuangan yang dikelolanya sejak data yang diperoleh hingga data tersebut dimusnahkan.

$$
\text { Berdasarkan ketentuan ini }
$$

perlindungan pemilik akun dari adanya penyalahgunaan akun yang disalahgunakan oleh pihak ketiga untuk melindungi data pribadi dalam undang - undang yang sudah di tentukan bahwa penyelenggara elektronik harus menjaga kerahasiaan dalam data 
pribadi bila terjadi kegagalan atau penyalahgunaan akun atau data pribadi maka pihak penyelenggara yaitu Traveloka harus memberitahukan kepada pemilik data pribadi. Pada Pasal 37 Peraturan Otoritas Jasa Keuangan Nomor 77/POJK.01/2016 Tentang Layanan Pinjam Meminjam Uang Berbasis Teknologi Informasi yang menjelaskan bahwa penyelenggara wajib bertanggung jawab atas kerugian pengguna yang timbul akibat kesalahan dan/atau kelalaian, direksi, dan/atau pegawai penyelenggara.

Kesimpulan 3.1 adalah perlindungan hukum internal menjelaskan bahwa perjanjian yang dilakukan oleh pihak Traveloka dan pihak pemilik akun. Perjanjian yang dilakukan oleh para pihak menimbulkan hubungan hukum dari pihak Traveloka dan pihak pemilik akun yang saling mengikat. Pembuatan perjanjian yang dilakukan oleh pihak Traveloka dalam syarat ketentuan harus memperhatikan syarat sahnya perjanjian yang terdapat pada Pasal 1320 KHUPerdata. Perjanjian yang dilakukan oleh pihak Traveloka dengan pihak pemilik akun salah satunya yaitu jika anda tidak memiliki control lagi atas akun tersebut, maka diperlukan agar segera melapor kepada Traveloka sehingga bisa memblokir semmentara dan/atau menonaktifkan akun anda. Kesepakatan yang diberikan pihak Traveloka harus menimbulkan hak dan kewajiban serta tidak memberatkan salah satu pihak, selanjutnya informasi - informasi dan perjanjian yang dilakukan pihak Traveloka harus memberikan dengan jelas dan disusun sesuai peraturan perundang - undangan.

Perlindungan hukum eksternal menjelaskan untuk melindungi pihak pemilik akun dari ketidakseimbangan jual beli melalui transaksi elektronik yaitu adanya penyalahgunaan akun yang telah disalahgunakan oleh pihak ketiga. Akun sendiri merupakan data pribadi pemilik akun yang diberikan kepada pihak penyelenggara elektronik seperti hal nama, password, nomor ktp, nomor kk, ataupun dari hal keuangan seperti kartu kredit dan bila terjadi adanya kegagalan atau adanya penyalahgunaan data pribadi yang salahgunakan penyelenggara elektronik yaitu Traveloka harus melindungi data pribadi dan bertanggung jawab bila terjadi kerugian atas kesalahan atau kelalaian dari pihak penyelenggara Traveloka sesuai dengan undang - undang yang sudah ada.

\section{Upaya Hukum Untuk Memulihkan} Kerugian Pemilik Akun Traveloka yang Disalahgunakan Oleh Pihak Ketiga

Upaya hukum Menurut Sudikno Mertokusumo ialah "Upaya atau alat untuk mencegah atau memperbaiki kekeliruan dalam sebuah putusan”. Upaya hukum adalah cara sah untuk mendapatkan perlindungan hukum dan keadilan yang dilindungi dan diatur oleh sebuah hukum. Upaya hukum sangat diperlukan antara subyek hukum dalam menyelesaikan sebuah sengketa yang terjadi. Pada umumnya ada 
beberapa sengketa yang terjadi antara subyek hukum antara lain :

a. Merasa dirugikan haknya oleh pihak lain sehingga menuntut keadilan;

b. Adanya ketidakpastian (keraguan) hukum sehingga harus mendapatkan kepastian hukum;

c. Adanya rasa harga diri yang diremehkan orang lain karena itu penting memperoleh penanganan baik secara psikologis, sosiologis maupun yuridis. 18

Upaya hukum merupakan hak asasi manusia terhadap setiap subyek hukum yang harus dilindungi konstitusi dan diatur oleh undang - undang. kewajiban yang diberikan oleh hukum perdata bisa terlihat dalam kontrak ataupun perjanjian yang telah dirancang oleh Traveloka dan pemilik akun. Akibat hukum dari adanya perjanjian yang telah disepakati dan sifat perdata yang terdapat pada hubungan hukum antara Traveloka dengan pemilik akun, maka demi hukum bila terjadi pelanggaran yang dilakukan oleh Traveloka yang dapat merugikan pemilik akun, menyerahkan kebebasan pada pemilik akun yang dapat meminta ganti rugi kemudian pihak Traveloka melakukan kewajibannya untuk bertanggung jawab memberikan ganti rugi kepada pemilik akun. Ganti rugi merupakan salah satu hak yang dimiliki oleh pemilik

18 Mukti Arto, Upaya Hukum Kasasi dan Peninjauan Kembali Perkara Perdata Agama, Ekonomi Syariah, dan Jinayah, Depok, Prenadamedia Group, 2018, hlm. 1. akun berdasarkan Undang - undang yang berlaku dan perlu ditegakkan. "Hak pemilik akun adalah hak untuk mendapatkan kompensasi, terhadap ganti rugi atau penggantian, apabila barang ataupun jasa yang diterima tidak sesuai dengan apa yang diperjanjikan". 19

Upaya hukum secara internal untuk mendapatkan ganti rugi yang ialamioleh pihak yang dirugikan menurut hukum yang ada di ketentuan hukum di Indonesia yang menjelaskan bahwa ada dua alasan berdasarkan dalam gugatan perdata yakni gugatan secara wanprestasi dan gugatan secara perbuatan melanggar hukum. Adapun dasar hukumnya yang terdapat di ketentuan pada Pasal 1243 KUHPerdata untuk Wanprestasi sedangkan pada Pasal 1365 KUHPerdata untuk Perbuatan Melawan Hukum. Gugatan wanprestasi selalu berhubungan dengan kontrak atau perjanjian antara kedua belah pihak. Perjanjian yang menimbulkan sisi aktif dan sisi pasif yang bersifat timbal balik antara para pihak. Sifat aktif akan menimbulkan sebuah hak bagi Kreditur untuk menuntut pemenuhan prestasi, sedangkan sifat pasif yang akan menimbulkan sebuah beban bagi debitur untuk melaksanakan prestasinya. Pada waktu saat prestasi tidak dilakukan atas perjanjian yang sudah disepakati sebagaimana mestinya, maka akan lahir apa yang dinamakan wanprestasi. Sedangkan gugatan perbuatan melawan hukum

19 Sukarmi, Op.Cit. hlm. 92 
merupakan dasar gugatan yang terdapat pada kepentingan hak yang dirugikan oleh perbuatan pihak lainnya dan perbuatan melawan hukum dalam melakukan gugatan tidak selalu dikarenakan adanya perbuatan yang bertentangan dengan undang - undang tetapi bisa juga menggugat dengan adanya perbuatan yang bertentangan dengan kewajiban hukum si pelaku, hak orang lain serta kesusilaan, kepatutan, dan kehati hatian. Selain itu hal yang dapat dikatakan perbuatan melawan hukum jika terdapat unsur kesalahan dan kesalahan itu dapat harus dipertanggung jawabkan kepada si pelaku.

Berdasarkan hal yang terjadi terhadap Traveloka dengan pihak pemilik akun untuk mendapatkan upaya hukum untuk memulihkan kerugian yang di dapat oleh pemilik akun Traveloka bisa menggugat didasarkan dengan perbuatan melawan hukum dan bukan perbuatan wanprestasi, yaitu dengan merujuk pada Pasal 1365 KUHperdata yang menjelaskan bahwa "Tiap perbuatan melanggar hukum yang membawa kerugian kepada seorang lain, mewajibkan orang yang karena salahnya menerbitkan kerugian itu, mengganti kerugian tersebut". Seorang yang telah dianggap melakukan perbuatan melakukan hukum akan mendapatkan sebuah sanksi dengan mengganti kerugian yang dialami oleh korban akibat adanya kesalahan, melalui tuntutan yang diajukan kepada Lembaga peradilan atau Lembaga penyelesaian sengketa diluar peradilan.
Namun dalam hal tersebut juga harus dapat dibuktikan dan dipertanggungjawabkan kebenarannya bila terjadi adanya Perbuatan Melawan Hukum melalui pembuktian unsur - unsur dari perbuatan melawan hukum yang terdiri dari :

1. Adanya Perbuatan Melawan Hukum.

2. Adanya kesalahan.

3. Adanya Kerugian.

4. Adanya hubungan sebab akibat antara perbuatan melawan hukum, kesalahan dan kerugian yang ada. 20

Perbuatan apa yang dilakukan oleh Traveloka yang sudah melanggar undang undang, bertentangan dengan hak orang lain, bertentangan dengan kewajiban hukum Traveloka seperti tidak melaksanakan tanggung jawab dari Traveloka itu sendiri serta Traveloka sudah lalai dalam menjaga akun dari pemilik akun yang sudah dititipkan terhadap pihak Traveloka sehingga terjadinya penyalahgunaan akun yang mengalami kebocoran data yaitu data subyek hukum yang disalahgunakan oleh oknum yang tidak bertanggung jawab sehingga pemilik akun mengalami sebuah kerugian atas kebocoran data tersebut yang digunakan untuk membeli tiket pesawat, hotel dll, dalam hal ini Traveloka harus bertanggung jawab terhadap kelalaian/kesalahan atas adanya

20 Hetti Hassanah, Analisis Hukum Tentang Perbuatan Melawan Hukum Dalam Transaksi Bisnis Secara Online (E-Commerce) Berdasarkan Burgerlijke Wetboek Dan Undang - Undang Nomor 11 Tahun 2008 Tentang Informasi Dan Transaksi Elektronik, Jurnal Wawasan Hukum, Volume 32 Nomor 1, 2015, Bandung, hlm. 48 
penyalahgunaan akun sehingga bisa dikatakan dalam pebuatan melawan hukum yang merupakan adanya unsur kesalahan oleh pihak Traveloka dan unsur kesalahan dapat dibuktikan maka pihak Traveloka sendiri harus bertanggung jawab atas kerugian yang disebabkan oleh perbuatannya, namun pihak Traveloka tidak hanya bertanggung jawab atas kerugian yang disebabkan oleh kesalahannya sendiri, tetapi juga karena perbuatan yang mengandung kesalahan yang dilakukan oleh orang yang menjadi tanggungannya dan yang berada dipegawasannya sebagaimana yang sudah dijelaskan pada Pasal 1366 KUHPerdata yang menjelaskan bahwa setiap orang bertanggung jawab tidak saja untuk kerugian yang disebabkan perbuatannya, tetapi juga untuk kerugian yang disebabkan kelalaian atau kurang hatihatinya dan Pasal 1365 KUHPerdata ini dapat digunakan sebagai dasar untuk mengajukan ganti kerugian atas perbuatan yang dilakukan secara melawan hukum dalam proses transaksi elektronik.

Upaya hukum dalam penyelesaian yang terjadi pada Traveloka juga bisa diselesaikan melalui beberapa upaya hukum atau sebuah alternatif yang dilakukan di luar pengadilan selain melalui gutatan perdata, para pihak dapat melakukan penyelesaian sengketa melalui sebuah lembaga lainnya sesuai dengan ketentuan apa yang sudah ada di dalam peraturan perundang - undangan yaitu menggunakan APS seperti mediasi, negoisasi, arbitrase, musyawarah, dan termasuk di dalam pengadilan yaitu litigasi.21 Sedangkan menurut Traveloka dalam menyelesaikan perselisihan yaitu "kedua pihak yang mengalami perselisihan harus dibicarakan dengan i'tikad baik sehingga mencapai kedamaian, dalam waktu 60 hari bila tidak ada kata sepakat dalam musyawarah akan dilanjutkan dengan melalui mediasi di Singapore Mediation Centre sesuai dengan prosedur mediasi saat ini, jika perselisihan tetap belum terselesaikan akan diajukan ke yurisdiksi eksklusif dari pengadilan Republik Singapura".

Selanjutnya upaya hukum dalam penyelesaian sengketa dengan menggunakan upaya hukum eksternal pada Pasal 26 Undang - Undang Nomor 19 Tahun 2016 Tentang Perubahan atas Undang - Undang Nomor 11 Tahun 2008 Tentang Informasi dan Transaksi Elektronik menjelaskan bahwa dalam penggunaan setiap informasi melalui media elektronik yang menyangkut data pribadi seseorang harus dilakukan atas persetujuan orang yang bersangkutan dan pada pasal ini menjelaskan setiap orang yang dilanggar haknya dapat mengajukan gugatan atas kerugian yang ditimbulkan berdasarkan Undang - Undang. Sedangkan dalam pasal 38 Undang - Undang Nomor 11 Tahun 2008 Tentang Informasi dan Transaksi Elektronik yang menurut pasal 38 tersebut :

21 Mukti Arto, Op.Cit., 
1. Setiap orang dapat mengajukan gugatan terhadap pihak yang menyelenggarakan sistem elektronik dan/atau menggunakan teknologi informasi yang menimbulkan kerugian.

2. Masyarakat dapat mengajukan gugatan secara perwakilan terhadap pihak yang menyelenggarakan sistem elekteronik dan/atau menggunakan teknologi informasi yang berakibat merugikan masyarakat, sesuai dengan ketentuan peraturan perundang - undangan.

Berdasarkan apa yang dijelaskan pada pasal 38 Undang - Undang Nomor 11 Tahun 2008 bahwa semua orang dapat mengajukan gugatan bila menimbulkan sebuah kerugian kepada penyelenggara sistem elektronik dengan cara melakukan gugatan secara perwakilan yaitu suatu cara melakukan pengajuan gugatan dalam mana satu orang atau lebih yang mewakili gugatan untuk dia atau dari dia mereka sendiri.

Lebih lanjut pada Pasal 39 Undang Undang Nomor 11 Tahun 2008 Tentang Informasi dan Transaksi Elektronik yang menjelaskan bahwa gugatan perdata dilakukan sesuai dengan ketentuan peraturan perundang - undangan. Selain penyelesaian gugatan perdata, para pihak dapat menyelesaikan sengketa melalui arbitrase, atau Lembaga penyelesaian sengketa alternative lainnya sesuai dengan ketentuan peraturan perundang undangan. Berdasarkan ketentuan dalam undang - undang nomor 11 tahun 2008 dalam melakukan gugatan perdata tidak ada kepastian hukum dalam penyelesaian sengketa dan tidak jelas mengatur mengenai arbitrase online, tetapi meminta kepada pihak untuk melakukan arbitrase secara konvensional.

Selanjutnya upaya dalam penyelesaian sengketa yang terdapat dalam transaksi elektronik yaitu terdapat pada Pasal 24 Peraturan pemerintah Nomor 71 Tahun 2019 Tentang Penyelenggara Sistem Dan Transaksi Elektronik yang menjelaskan bahwa :

1. Penyelenggara Sistem Elektronik wajib memiliki dan menjalankan prosedur dan sarana untuk pengaman sistem elektronik dalam menghindari gangguan, kegagalan, dan kerugian.

2. Penyelenggara sistem elektronik wajib menyediakan sistem pengaman yang mencakup prosedur dan sistem pencegahan dan penanggulangan terhadap ancaman dan serangan yang menimbulkan gangguan, kegagalan, dan kerugian.

3. Dalam hal terjadi kegagalan atau gangguan sistem yang berdampak serius akibat perbuatan dari pihak lain terhadap sistem elektronik, penyelenggara sistem elektronik wajib mengamankan informasi elektronik dan/atau dokumen elektronik dan segera melaporkan dalam kesempatan pertama kepada aparat penegak hukum, kementerian atau Lembaga terkait. 
Berdasarkan ketentuan yang di berikan pada pasal 24 ini yang menjelaskan penyelenggara sistem elektronik harus menjaga atau mengaman sistem elektronik dari gangguan - gangguan dari pihak lain yang dapat merugikan dan bila terdapat kegagalan atau gangguan dalam sistem maka harus melakukan pengaduan kepada penegak hukum.

Upaya hukum perlindungan pemilik akun dalam pada Pasal 29 Permenkominfo Nomor 20 Tahun 2016 Tentang Perlindungan Data Pribadi Dalam Sistem Elektronik menjelaskan Mekanisme penyelesaian sengketa bahwa :

1) "setiap pemilik data pribadi dan penyelenggara sistem elektronik dapat mengajukan pengaduan kepada Menteri atas kegagalan perlindungan kerahasiaan data pribadi".

2) "pengaduan sebagaimana yang dimaksud pada ayat (1) dimaksudkan sebagai upaya penyelesaian sengketa secara musyawarah atau melalui penyelesaian alternatif lainnya".

3) "pengaduan sebagaimana yang dimaksud pada ayat (1) dilakukan berdasarkan alasan :"

a. "Tidak dilakukannya pemberitahuan secara tertulis atas kegagalan perlindungan rahasia data pribadi oleh penyelenggara sistem elektronik kepada pemilik data pribadi atau penyelenggara sistem elektronik lainnya yang terkait dengan data pribadi tersebut, baik

yang berpotensi maupun tidak berpotensi menimbulkan kerugian".

b. "Telah terjadinya kerugian bagi pemilik data pribadi atau penyelenggara sistem elektronik lainnya yang terkait dengan kegagalan perlindungan rahasia data pribadi tersebut, meskipun telah dilakukan pemberitahuan secara tertulis atas kegagalan perlindungan rahasia data pribadi namun waktu pemberitahuannya yang terlambat".

4. "Menteri dapat berkoordinasi dengan pimpinan instansi pengawas dan pengatur sektor untuk menindaklanjuti pengaduan sebagaimana yang dimaksud pada ayat (1)".

Ketentuan yang diberikan pada Pasal 29 Permenkominfo Nomor 20 Tahun 2016 menjelaskan bahwa dalam adanya gangguan atau adanya penyalahgunaan akun dalam sistem elektronik seperti kebocoran data pribadi dapat melakukan pengaduan kepada Menteri atas kegagalan yang terjadi dan mengalami sebuah kerugian yang diakibatkan adanya penyalahgunaan akun serta memberikan bukti - bukti bahwa telah terjadi gangguan atau penyalahgunaan akun bila ingin mengadu kepada menteri.

\section{SIMPULAN}

Berdasarkan pembahasan pada bab sebelumnya, maka dapat ditarik kesimpulan sebagai berikut :

\section{Universitas Trunojoyo Madura}


1. Bentuk perlindungan hukum internal bagi pemilik akun Traveloka adalah saat sebelum melakukan perjanjian dalam melakukan transaksi jual beli, pemilik akun Traveloka harus mempelajari terlebih dahulu syarat dan ketentuan yang dibuat oleh pihak Traveloka supaya tidak dapat merugikan salah satu pihak. Suatu perjanjian atau kontrak yang dibuat oleh kedua belah pihak harus menimbulkan akibat hukum pada pasal 1338 KUHPerdata dan pembuatan perjanjian dalam syarat dan ketentuan yang dibuat oleh Traveloka dalam melakukan transaksi jual beli harus diperhatikan syarat sahnya perjanjian atau kontrak terdapat pada pasal 1320 KUHPerdata. Perjanjian yang diberikan pihak Traveloka harus menimbulkan hak dan kewajiban serta tidak memberatkan salah satu pihak, selanjutnya informasi - informasi dan perjanjian yang dilakukan pihak Traveloka harus memberikan dengan jelas dan disusun sesuai peraturan perundang - undangan. Bentuk perlindungan hukum eksternal untuk melindungi pihak pemilik akun dari ketidakseimbangan jual beli melalui transaksi elektronik yaitu adanya penyalahgunaan akun yang telah disalahgunakan oleh pihak ketiga. Akun sendiri merupakan data pribadi pemilik akun yang diberikan kepada pihak penyelenggara elektronik bila terjadi adanya kegagalan atau adanya penyalahgunaan data pribadi yang disalahgunakan, penyelenggara elektronik yaitu Traveloka harus melindungi data pribadi dan bertanggung jawab bila terjadi kerugian atas kesalahan atau kelalaian dari pihak penyelenggara Traveloka sesuai dengan undang - undang yang sudah ada yang diatur dalam pasal 31 Peraturan Pemerintah Nomor 71 Tahun 2019 Tentang Penyelenggara Sistem dan Transaksi Elektroni yang menjelaskan bahwa dalam pasal ini penyelenggara system elektronik harus melindungi pemilik akun atas penggunaan system elektonik aatas kerugian yang terjadi .

2. Upaya dalam penyelesaian sengketa dapat dilakukan melalui upaya hukum secara internal dengan melakukan gugatan secara Perbuatan Melawan hukum dan selain melaui gugatan bisa melalui mediasi, negoisasi, arbitrase musyawarah dan litigasi. Upaya penyelesaian perselisihan yang diberikan oleh pihak Traveloka perselisihan bisa dengan cara musyawarah bila tidak ada kata sepakat bisa dilanjutkan dengan mediasi, jika perselisihan belum terselesaikan maka akan dilanjutkan ke yurisdiksi eksklusif dari pengadilan Republik Singapura. Upaya hukum secara eksternal bisa menggunakan dari Undang - undang Nomor 11 Tahun 2008 Tentang Informasi dan Transaksi Elektronik, Peraturan Pemerintah Nomor 71 Tahun 
2019 Tentang Penyelenggara Sistem dan

Transaksi Elektronik dan

Permenkominfo Nomor 20 Tahun 2016

Tentang Perlindungan Data Pribadi

Dalam Sistem Elektronik. Berdasarkan

kententuan yang telah ada upaya hukum dengan cara melakukan pengaduan bila terjadi sebuah kerugian.

\section{DAFTAR RUJUKAN \\ Buku}

Ali, Zainuddin, (2016), Metode Penelitian Hukum. Jakarta: Sinar Grafika.

Aprita, Serlika. (2019), Perlindungan Hukum Bagi Pemegang Saham Minorita, Kreditor Karyawan Atas Akuisisi Perusahaan. Jember: CV Pustaka Abadi.

Arto, Mukti, (2018), Upaya Hukum Kasasi dan Peninjauan Kembali Perkara Perdata Agama, Ekonomi Syariah, dan Syariah. Depok : Prenadamedia Group.

Astri, Rumondang (2019), Fintech: Inovasi Sistem Keuangan di Era Digital, Yayasan Kita menulis.

Diantha, I Made Pasek (2016), Metodologi Penelitian Hukum Normatif dalam Justifikasi Teori Hukum, Prenada Media Group.

Hardani, I Putu. (2018), Tiket Penerbangan Dosmestik. Yogyakarta: Deepublish.

Ibrahim, Jhony. (2007), Teori Dan Metodelogi Penelitian Hukum Normatif. Malang: Bayumedia Publishing.

Marzuki, Peter Mahmud, (2016), Penelitian Hukum Edisi Revisi, Jakarta: Prenada Media Group.
Moch. Isnaeni, (2016), Pengantar Hukum Jaminan Kebendaan, Surabaya: Revka Petra Media.

Mukti Fajar dan Yulianto Achmad, (2015), Dualisme Penelitian Hukum Normatif \& Empiris. Yogyakarta. Pustaka Pelajar.

Isnawati. (2018), Jual Beli Online Sesuai Syariah, Jakarta Selatan. Rumah Fiqih Publishing.

Purwati, Ani, (2020), Metode Penelitian Hukum Teori dan Praktek. Surabaya. CV Jakad Media Publishing.

Rosmawati, (2018), Pokok - pokok Hukum Perlindungan Konsumen. Depok. Prenadamedia Group.

Sadi, Muhammad, (2015), Pengantar Ilmu Hukum. Jakarta. Kencana.

Sarwono, Jonathan dan Prihartono. (2012), Perdagangan Online: Cara Bisnis di Internet. Jakarta. PT Elex Media Komputindo.

Shidarta, (2006), Hukum Perlindungan Konsumen Indonesia, Jakarta. Gramedia Widiasarana Indonesia.

Sri, Adiningsih, dkk, (2019), Transformasi Ekonomi Berbasis Digital di Indonesia: Lahirnya Tren Baru Tekhnologi, Bisnis, Ekonomi, dan Kebijakan di Indonesia. Jakarta: Gramedia Pustaka Utama.

Sukarmi. (2008), Cyber Law Kontrak Elektronik Dalam Bayang - Bayang Pelaku Usaha. Bandung: Pustaka Sutra.

Wahyuni, Hermin Indah (2013), Kebijakan Media Baru Di Indonesia. Yogyakarta : Gadjah Mada University Press.

Wuria Dewi, Eli, (2015), Hukum Perlindungan Konsumen, Yogyakarta: Graha Ilmu.

Jurnal

Universitas Trunojoyo Madura 
Achjari, Didi. (2000). "Potensi Manfaat dan Problem Di E-commerce". Jurnal Ekonomi dan Bisnis Indonesia. Volume 15 Nomor 3.

Adriati, Riery, Zarfinal, Suamperi. (2013), "Perjanjian Jual Beli Tiket Elektronik (E-Ticket) Maskapai Penerbangan Melalui Internet (Studi Kasus Garuda Indonesia), Fakulty Of Law Bung Hatta University. Volume 2 Nomor 1.

Ahmad, Sufmi Dasco. (2018). "Peranan Otoritas Jasa Keuangan Dalam Penanggulangan Investasi Ilegal Di Indonesia", Privat Law. Volume 6 Nomor 1.

Hassanah Hetti.(2015). “Analisis Hukum Tentang Perbuatan Melawan Hukum Dalam Transaksi Bisnis Secara Online (E-Commerce) Berdasarkan Burgerlijke Wetboek Dan Undang Undang Nomor 11 Tahun 2008 Tentang Informasi Dan Transaksi Elektronik", Jurnal Wawasan Hukum, Volume 32 Nomor 1.

Paat, Lianthy Nathania, (2020). "Kajian Hukum Terhadap Cyber Bullying Beradasarkan Undnag - Undang Nomor 19 Tahun 2016", Lex Crimen, Volume. IX Nomor 1.

Marwani, Rika. (2016). "Perlindungan Hukum Bagi Para Pihak Dalam Transaksi Ecommerce Melalui Facebook", Jurnal Hukum Progresif, Volume X Nomor 1.

Njatrijani, Rinitami. (2019). “Perkembangan Regulasi dan Pengawasan Financial Technology Di Indonesia", Diponegoro Private Law Review. Volume 4 Nomor 1.

Pratama, Geistiar Yoga. (2016). "Perlindungan Hukum Terhadap Data Pribadi Pengguna Jasa Transportasi Online Dari Tindakan Penyalahgunaan Pihak Penyedia Jasa Berdasarkan Undang - Undang Nomor 8 Tahun 1999 Tentang Perlindungan
Konsumen". Diponegoro Law Journal. Volume 5 Nomor 3.

Priyambodo, Sigit. (2019). "Perlindungan Hukum Bagi Nasabah Debitur Terhadap Penetapan Bunga Bank Yang Tidak Sesuai Dengan Peraturan Perundang Undangan Dalam Perjanjian Kredit”. Jurnal Media Hukum dan Peradilan. Volume 5 Nomor 1.

Program Studi Akuntansi FEB Univ. Ma Chung, (2018). Studi Kasus Sistem Informasi Manajeman, Malang. Volume 2.

Winarno, Wahyu Agus. (2011). "Sebuah Kajian Pada Undang - Undang Informasi dan Transaksi Elektronik (UU ITE), JEAM, Volume X Nomor 1.

Yusmita, dkk. "Perlindungan Hukum Terhadap Penerimaan Pinjaman Uang Berbasis Teknologi Informasi”. Jurnal Akrab Juara. Volume 4 Nomor 5.

\section{Peraturan Perundang - undangan}

Peraturan Otoritas Jasa Keuangan Nomor 77/POJK.01/2016 Tentang Layanan Pinjam Meminjam Uang Berbasis Teknologi Informasi, Lembaran Negara Republik Indonesia Tahun 2016 Nomor 324

Subekti, R, dan R. Tjitrosudibio, Kitab Undang Undang Hukum Perdata (KUH Perdata), Pradnya Paramita, Jakarta, 2004.

Undang - Undang Nomor 8 Tahun 1999 Tentang Perlindungan Konsumen, Lembaran Negara Republik Indonesia Tahun 1999 Nomor 42, Tambahan Lembaran Negara 3821.

Undang - Undang Nomor 19 Tahun 2016 Tentang Perubahan Atas Undang Undang Nomor 11 Tahun 2008 Tentang Informasi Dan Transaksi Elektronik, Lembaran Negara Republik Indonesia Tahun 2008 
Nomor 58, Tambahan Lembaran Negara 4843.

\section{Internet}

Finansial.com, "Kelebihan dan Kelemahan Fintech", dikutip dari https://www.finansialku.com/kelebih an-dan-kelemahan-fintech/, <diunduh tanggal 7 mei 2020>

Kamus Besar Bahasa Indonesia (KBBI), "Internet", dikutip dari http://www.google.com/amp/s/kbbi. web.id/interent.html, <diunduh tanggal 13 maret 2020>

Media Konsumen, "Akun Traveloka Saya Dibobol dan Fasilitas Paylater
Disalahgunakan", dikutip dari http://mediakonsumen .com/2019/02/19/suratpembaca/astagfirullah-akuntraveloka-saya-dibobol-dan-fasilitaspaylater-disalahgunakan/amp\#, $<$ diunduh tanggal 9 Maret 2020>

Temukan Pengertian, "Pengertian Account Dalam Internet dan Jenis - jenis Account', dikutip dari http://www.temukanpengertian.com/ 2013/01/pengertian-account.html, <diunduh tanggal 13 Maret 2020>.

Traveloka, "Syarat dan Ketentuan", dikutip dari https://www.traveloka.com/idid/termsandconditions. <diakses tanggal 20 juni 2020>. 